\title{
A IRONIA COMO DESLOCAMENTO NO EFEITO DE LINEARIDADE E IMPARCIALIDADE DO DISCURSO JORNALÍSTICO
}

\author{
Eliane Righi de Andrade*
}

\begin{abstract}
RESUMO: Este trabalho, numa perspectiva discursiva, tem como objetivo discutir o funcionamento da ironia dentro do discurso jornalístico, o qual rompe com a pretensa linearidade e imparcialidade desse discurso. Para a constituição de nosso corpus de pesquisa e análise, selecionamos recortes de reportagens e quadrinhos extraídos de diferentes edições diárias de um jornal, os quais se relacionam a um acontecimento muito narrado e comentado pela mídia. Através da análise da materialidade lingüistica, no confronto entre diferentes discursos e textos, podemos concluir que o discurso jornalístico, constitutivo da memória discursiva, está sujeito também à porosidade da língua e seu caráter equívoco, aflorados nos efeitos de estranhamento e de humor provocados pela ironia.
\end{abstract}

PALAVRAS-CHAVE: Ironia - Discurso Jornalístico - Memória Discursiva

ABSTRACT: This essay intends to discuss, from a discursive perspective, the way irony works in the journalistic discourse, breaking with its apparent impartiality and linearity. For this purpose, we are going to use, as our research corpus, some pieces of news and some cartoons which were printed in a newspaper about a mediatic event. By analyzing the linguistic materiality, different discourses and texts, we can conclude that the journalistic discourse, which is part of the discursive memory, is also subject to the language porosity and equivocacy, which come out in humor and strangeness effects on the language surface.

KEY-WORDS: Irony - Journalistic Discourse - Discursive Memory

\section{PROPOSTA DE TRABALHO}

Partindo-se do pressuposto de que o jornal é um elemento constitutivo da memória discursiva, que cria e reproduz um imaginário muito mais pelos efeitos de sentido que provoca do que pelos fatos que narra, já que os acontecimentos são submetidos a um olhar imerso na historicidade, considerando as formações discursivas que o discurso jornalístico representa e dá voz, neste estudo, temos como objetivo discutir a presença da ironia como um funcionamento da linguagem bastante comum nesse discurso, em que a objetividade, a imparcialidade e a transparência da linguagem são colocadas em questão. A ironia se coloca, aqui, como um processo de construção na língua que estabelece o diálogo entre textos e outros discursos que constituem o jornal (mas não só ele) e que remetem ao acontecimento jornalístico, o qual propomos analisar: os ataques do PCC no mês de maio em São Paulo e o revide policial a eles -, fazendo interagir, na análise, as duas bases discursivas: a língua e o acontecimento, num processo simultâneo e articulado de descrição e interpretação.

\footnotetext{
* Doutoranda no programa de Lingüística Aplicada do IEL-Unicamp.Email: elianerighi@terra.com.br
} 


\title{
CONDIÇÕES DE PRODUÇÃO E DEFINIÇÃO DO CORPUS
}

Para darmos início a essa análise de natureza discursiva, é importante articularmos os dois elementos fundamentais que a suportam: a estrutura (língua) e o acontecimento (momento histórico-social), na descrição das condições em que foram produzidos os discursos. A escolha, portanto, de recortes discursivos sobre as ações do PCC e da polícia selecionados da mídia impressa e a repercussão desses discursos em diferentes formações discursivas permitirão realizar gestos de interpretação que abarquem o imaginário e a memória construída a partir desse complexo evento.

Primeiramente, quando nos referimos, de modo geral, às ações do PCC, consideramos, na verdade, para a análise, um conjunto de recortes discursivos que descreve, "fala" sobre os acontecimentos que ocorreram em meados do mês de maio de 2006, nomeados e caracterizados pela mídia impressa e televisiva como Guerra Urbana. Várias ações estão articuladas ao evento descrito: diversos atentados à polícia civil e militar, a agentes carcerários; rebeliões em presídios, principalmente no Estado de São Paulo, mas com ramificações por outras regiões, tais como Paraná e Mato Grosso; mortes e atentados a familiares de policiais e de agentes penitenciários; lançamentos de bombas a delegacias e postos policiais; incêndios a ônibus e agências bancárias e, como resposta e retaliação a essas ações, prisões e mortes de suspeitos realizadas pela polícia, além de um caos generalizado nas cidades paulistas mais atingidas: transporte fora de circulação, escolas sem aulas, comércio fechado e muito pânico. Vejamos algumas das manchetes que circularam na terça-feira, dia 16 de maio, quarto dia após a deflagração da chamada Guerra Urbana, no jornal Folha de S. Paulo, no caderno Cotidiano:

\author{
Onibus param, e 5,5 milhões de pessoas ficam a pé \\ Por precaução, shoppings fecham lojas \\ Caos faz celulares entrarem em pane \\ Alvo de ataques, agências não abrem \\ Fóruns encerram expediente mais cedo \\ Medo faz 40\% dos colégios fecharem: universidades suspendem aulas \\ Quinze suspeitos morrem no quarto dia
}

Nas páginas centrais duplas do caderno Cotidiano do jornal, caderno que foi editado em 18 páginas (normalmente ocupa 8 páginas), há um conjunto de fotos mostrando cenas da cidade de São Paulo no dia anterior e um mapa localizando todos os atentados, com a manchete em letras garrafais, ao centro da página dupla: $O$ dia em que SP parou.

Na mídia televisiva não foi diferente. Na maior das redes abertas (Globo), por exemplo, houve cobertura diária, com entrevistas ao vivo com autoridades responsáveis pela segurança no estado de São Paulo (como o secretário de segurança Saulo de Abreu Filho, por exemplo) e especialistas em segurança pública. Em outra rede (Rede TV), um jornalista, em seu programa diário, fez o mesmo, em tom altamente sensacionalista, como comentou outro jornalista, Nelson de Sá, em coluna da Folha de S. Paulo, (SÁ, 19/5/2006, p. 6), denominada Toda Mídia, na qual aborda o trabalho de diferentes veículos de comunicação sobre o evento da Guerra Urbana. A Rede Bandeirantes vinculou em sua programação uma suposta entrevista com Marcola, o líder máximo do PCC (Primeiro Comando da Capital), e, na Record, uma outra entrevista foi divulgada 
com outro possível líder da organização criminosa, Macarrão. Portanto, tal conjunto de eventos teve grande repercussão na mídia, não só impressa, o que teria levado, na opinião dos envolvidos com a segurança pública, a uma onda de pânico e de boatos generalizada, com pronunciamentos também nos meios de comunicação que buscassem acalmar a situação. Na edição do dia 16 de maio do mesmo jornal, outra manchete do caderno Cotidiano também indicava: Governo de SP culpa boatos por pânico.

Não nos cabe, neste trabalho, julgar o que realmente aconteceu ou não nesse episódio, até porque a verdade que se coloca como posse do discurso jornalístico, o qual se diz imparcial, objetivo e informativo, não deixa de ser apenas uma "vontade de verdade", como coloca Foucault $(2004 ; 2002)$, uma criação humana realizada a partir de um regime discursivo, que se constrói nas relações de poder e saber, ou, na concepção pecheutiana, no assujeitamento do indivíduo à ideologia que o submete e o condiciona historicamente (PÊCHEUX e FUCHS, 1990), através de sua filiação às várias formações discursivas.

Por seu caráter analítico-discursivo, buscaremos, na análise, sugerir efeitos de sentido que afloram na materialidade lingüística dos recortes discursivos selecionados, os quais compuseram o corpus do analista. Metodologicamente, teremos em mente os procedimentos que Pêcheux (1997) levanta para a análise de discurso em Discurso: estrutura ou acontecimento. Primeiramente, segundo o autor, o acontecimento é considerado como o fato novo em seu contexto atual e no espaço de memória que ele convoca (ibid., p. 19). Para ele, muitas vezes, o enunciado fica "pregado" ao acontecimento, sobredeterminando-o, fazendo com que marcas e objetos simbólicos estejam associados a ele e tornando o ato da interpretação já pré-concebido.

Assim, o sentido (único) aparece como algo logicamente estabilizado e que foge, portanto, das contradições constitutivas do discurso, dos conflitos do sujeito que enuncia em diferentes posições discursivas e, enfim, do caráter equívoco da língua e de sua opacidade. Segundo Pêcheux, o "problema principal é determinar nas práticas de análise de discurso o lugar e o momento da interpretação, em relação aos da descrição" (ibid., p. 54), tendo em mente que não se trata de fases que se sucedem, mas que caminham juntas no processo da análise. No entanto, como observa, ainda, o autor, a descrição remete a interpretações que são demarcadas pelo jogo da língua no discurso, por lugares vazios, pelo silêncio, pelos lapsos e equívocos que o povoam, pela multiplicidade de sentidos filiados ao espaço social e histórico (formações discursivas), colocando em cena o "discurso-outro como espaço virtual de leitura" (ibid., p. 55) dos enunciados que compõem as seqüências discursivas.

Para finalizar essas primeiras observações, citamos mais uma vez Pêcheux para demarcar o espaço e o processo que envolve a análise discursiva:

\footnotetext{
A posição de trabalho que aqui evoco em referência à análise de discurso não supõe de forma alguma a possibilidade de algum cálculo dos deslocamentos de filiação e das condições de felicidade ou de infelicidade evenemenciais. Ela supõe somente que, através das descrições regulares de montagens discursivas, se possa detectar momentos de interpretações enquanto atos que surgem como tomadas de posição, reconhecidas como tais, isto é, como efeitos de identificação assumidos e não negados (ibid., p. 57).
}

Esse é o trabalho que nós, como analistas, nos propomos a realizar sobre o corpus, tomando o cuidado de não reduzir o acontecimento à estrutura, de não antecipar sentidos ou apagar o acontecimento em sua dimensão histórico-discursiva, e de 
apreendê-lo como efeito das diversas filiações sociais e das determinações inconscientes. Essa tomada de posição parece-nos o grande desafio.

\section{O PAPEL DO DISCURSO JORNALÍSTICO NA CONSTRUÇÃO DA MEMÓRIA}

Ao compartilharmos a posição de Mariani (2003) de que o discurso jornalístico é fator constitutivo na formação da memória, pensamos que a imprensa é responsável - e foi responsável, especificamente, na construção discursiva desse evento - pela "seleção dos acontecimentos que serão recordados no futuro" e, uma vez que fixa certos sentidos, também "acaba por constituir no discurso um modo (possível) de recordação do passado" (ibid., p. 33). Assim, a imprensa em geral é capaz, como prática social e discursiva que é, de produzir certos sentidos e de contribuir para a constituição do imaginário de uma época, uma vez que se apresenta como porta-voz de várias vozes, de diferentes formações discursivas que se entrelaçam, revelando as relações de poder que se estabelecem entre elas.

Assim, por exemplo, quando nos referimos aqui à Guerra Urbana, expressão que foi cunhada pela imprensa para descrever os eventos ocorridos no mês de maio de 2006, principalmente em São Paulo, nos apropriamos de um termo que foi usado para descrever tal acontecimento, o qual remete a toda uma condição histórico-social do momento, mas que também implica sentidos prévios que estão imersos no interdiscurso: em uma guerra há os dois lados - o do bem e o do mal, por exemplo. Por ser de natureza urbana, coloca em destaque o espaço social em que esta foi gerada, as cidades grandes, relevando todos os problemas sociais produzidos nesse meio: a miséria, a falta de oportunidades, a insegurança, a violência, etc. Portanto, abordando por uma perspectiva discursiva, a imprensa expõe posições que os sujeitos assumirão, de acordo com suas formações discursivas, nesse imaginário sobre a guerra urbana, numa sociedade tipicamente de controle (FOUCAULT, 2001).

Há certos sentidos estabilizados nesse discurso (viver em cidades grandes é uma luta e ameaça constantes, por exemplo), que tentam validar certas verdades vinculadas pelo discurso jornalístico. No entanto, a materialidade da língua que se concretiza no discurso nos coloca em uma armadilha: há possibilidades do sujeito não se enquadrar nessas significações, resistir a elas e criar novos gestos de interpretação, pondo em xeque a transparência da língua. Assim, um discurso pode produzir diferentes efeitos de sentido em quem o interpreta, os quais se constroem em sua historicidade.

Pêcheux (1999) faz uma observação em relação à memória que nos parece bastante pertinente a este estudo ao lidar com o papel do discurso jornalístico como participante na construção da memória:

\footnotetext{
...uma memória não poderia ser concebida como uma esfera plena, cujas bordas seriam transcendentais históricos e cujo conteúdo seria um sentido homogêneo, acumulado ao modo de um reservatório: é necessariamente um espaço móvel de divisões, de disjunções, de deslocamentos e de retomadas, de conflitos de regularização... Um espaço de desdobramentos, réplicas, polêmicas e contra-discursos (ibid., p. 56).
}

O autor refere-se ao real histórico da memória como aquele que é constituído tanto do que lhe é interno quanto externo, já que um remete-se ao outro, pois não há 
"um frasco sem exterior" (PÊCHEUX, 1999, p. 56). Esse processo de construção da memória em que o discurso jornalístico tem participação remete a outros dois conceitos de Pêcheux: o de interdiscurso, entendido aqui como a memória discursiva que se forma a partir do que se pode ou não dizer, dentro de cada formação discursiva, e de intradiscurso, que se caracteriza pelas formulações consideradas no momento real de sua enunciação. Desse modo, como afirma Brandão (1995, p. 79), a memória discursiva é engendrada - e regulada - nas e pelas práticas discursivas, cujos enunciados se constroem a partir de uma condição histórica, o que remete também aos sistemas de exclusão e de rarefação do discurso, descritos por Foucault (2002), em $A$ ordem do discurso.

O discurso jornalístico, portanto, exerce, sobre a memória discursiva, esse tipo de regulação e de controle, sendo responsável por divulgar, num determinado contexto histórico, aquilo que é aceito e apagar aquilo que não pode ser dito, de acordo com as relações de poder representadas pelas formações discursivas. Portanto, segundo Mariani (2003, p. 33) ele tem papel fundamental na constituição dos fatos presentes, mas também no que será engendrado para o futuro como possibilidade de leitura e, conseqüentemente, na organização da memória instituída para o passado.

No entanto, como aborda Pêcheux (1988, p. 304), "não há dominação sem resistência (...) [e] ninguém pode pensar do lugar de quem quer que seja" ou, ainda, que "não há identificação plenamente bem sucedida, isto é, ligação sócio-histórica que não seja afetada, de uma maneira ou de outra, por uma 'infelicidade' no sentido performativo do termo" (PÊCHEUX, 1997, p. 56, grifo do autor). Por isso, este trabalho busca, na análise dos recortes discursivos, momentos em que se rompem os sentidos semanticamente estabilizados e que o equívoco da língua emerge. Regiões do discurso bastante férteis para essa aparição, como observa Pêcheux (1997, p. 53), são o humor e a poesia. Daí, dentro do discurso jornalístico - que também não é homogêneo -, nossa escolha em selecionar, para compor o corpus de análise, momentos privilegiados da emergência do equívoco da língua, utilizando, principalmente, como recortes discursivos, quadrinhos humorísticos, os quais também realizaram sua leitura sobre a Guerra Urbana, e outros fragmentos de dizeres de outros enunciadores, focando-nos em momentos em que a ironia é estruturante nesses discursos do jornal, o que remete à ambigüidade constitutiva dos discursos e dos sujeitos.

Se o espaço para o equívoco na língua se dá através de lapsos, chistes, trocadilhos, etc. - que caracterizam o lugar privilegiado do humor na língua -, no discurso jornalístico, ele emerge com freqüência no uso da ironia, uma vez que esta rompe com a aparente objetividade desse discurso, abrindo portas para diferentes interpretações (para o duplo sentido, por exemplo). É necessário, portanto, que façamos, aqui, algumas considerações teóricas no âmbito do humor, da ironia, da ambigüidade $\mathrm{e}$ do equívoco para que possamos, enfim, procedermos a análise.

Como parte do material discursivo utilizado são os quadrinhos, não há como não se focar nas ilustrações que os compõem, o que implica em dizer que parte do material textual é formado por imagens que são altamente significativas em conjunto com a linguagem verbal, produzindo efeitos de ironia. 


\title{
O PAPEL DO HUMOR NA EMERGÊNCIA DO EQUÍVOCO/AMBIGÜIDADE
}

Brait (1996, p. 13-14), em seu estudo discursivo sobre a ironia, aborda-a como um aspecto particular do humor, nem sempre associado ao riso, definindo-a como um "processo discursivo passível de ser observado em diferentes manifestações de linguagem":

\begin{abstract}
A ironia, seu efeito humorado, tanto pode revelar-se via um chiste, uma anedota, uma página literária, um desenho caricatural, uma conversa descontraída ou uma discussão acirrada, espaços 'institucionalizados' para o aparecimento de discursos de humor, quanto em outros, como a primeira página de um jornal sério que não tem por objetivo divertir seus leitores (ibid., p. 13-14, grifo do autor).
\end{abstract}

Através da análise das construções que abordam o humor, aqui estruturadas pela ironia, podemos, portanto, ter acesso a certos efeitos de sentido que remetem a aspectos de uma determinada sociedade e cultura, uma vez que a manifestação humorística pode trazer à tona aspectos não revelados em diferentes discursos (como o jornalístico, por exemplo), considerados semanticamente normais ou sérios. A autora também levanta a hipótese de que, muitas vezes, o humor ou a ironia podem também ser responsáveis por disseminar ou estabelecer preconceitos. Através da análise, poderemos, de fato, refletir sobre o papel do humor e da ironia na discursivização dos acontecimentos focados sempre em relação a outros discursos (interdiscurso) e textos (intertextualidade), instaurando, então, a polifonia. Nesse caso, não há como negar a participação do destinatário para que a ironia se concretize como processo discursivo, uma vez que os efeitos de sentido mobilizam também outras interpretações, sem as quais os enunciados poderiam apenas remeter-se ao discurso sério ou menos crítico que a ironia busca romper. A ruptura se dá como o fim da ilusão de um sentido uno e da língua transparente.

A ironia aborda sempre uma visão dialética da construção discursiva, a "idéia da contradição, de duplicidade como um traço essencial a um modo de discurso dialeticamente articulado; o distanciamento entre o que é dito e o que o enunciador pretende que seja entendido" (ibid., p. 29), o que está bastante vinculado à idéia da opacidade da língua e do equívoco constitutivo da mesma.

Há uma aproximação teórica do conceito de interferência de séries, desenvolvido por Bergson (1983), que caracteriza a ironia, com as formações ideológicas e formações discursivas da análise do discurso, uma vez que elas podem ser sugeridas na materialidade lingüística do discurso. A interferência de séries indica uma sobreposição, ou melhor, a coexistência entre discursos e textos (interdiscursividade e intertextualidade), o que lhe confere o caráter da polifonia. Brait (1996, p. 36) aponta para o fato de que essa interferência, no discurso jornalístico, pode-se dar entre imagem e texto, entre a justaposição de segmentos discursivos que remetem a diferentes formações discursivas, mas que, em sua articulação, provocam, como efeito de sentido, a ironia.

Portanto, a ironia não é inerente ao fato, mas um funcionamento da linguagem que se marca na construção da língua, instaurando um discurso dito ambíguo. No entanto, uma vez que nos referimos a uma visão de língua opaca, a ambigüidade será sempre constitutiva a ela. Portanto, em vez de remeter ao caráter dual do ambíguo, preferimos pensar em multiplicidade de sentidos. 
No caso do discurso jornalístico, por exemplo, a ironia pode ser causada nos momentos em que a linguagem dita informativa e objetiva se alia a elementos que provocam o riso, tais como imagens ou referências não-explícitas ${ }^{1}$ a outros textos e discursos, numa conjunção de elementos que não eram esperados naquele espaço discursivo. A coexistência, por exemplo, de diversos discursos, tais como o religioso, o esportivo, o político, com o discurso jornalístico informativo pode provocar a ironia.

Segundo Brait (1996), ainda, a ironia estaria relacionada ao campo da enunciação e não do enunciado, daí a necessidade do compartilhamento de saberes entre enunciador e enunciatário. O primeiro, ao mesmo tempo em que simula uma verdade na língua, referencia essa simulação no discurso, que é percebida pelo enunciatário, evidenciando a duplicidade (ambigüidade) enunciativa do processo (lingüística e discursiva). Portanto, a ironia, como um mecanismo de funcionamento da língua, faz a subversão de sentidos pré-estabelecidos, contribuindo para a desestabilização dos significados semanticamente estabilizados, como salienta Pêcheux (1997), e para a irrupção do equívoco da língua, uma vez que, segundo Brait (1996, p. 108), nesse momento, evidencia-se a "ruptura que o tempo todo tende a ser suturada para tornar o discurso um".

Orlandi (1986), em seu estudo sobre a ironia, faz outras considerações sobre esse funcionamento da linguagem. Para a autora, a produção de sentidos está, de muitas formas, condicionada pela história, ou seja, pela articulação das práticas discursivas e não-discursivas. Daí a ironia, como elemento desse funcionamento discursivo, também ser legitimada historicamente e estruturar certos tipos de discurso, o que lhe confere, segundo a autora, a natureza de uma "prática de linguagem circunstanciada" (ibid., p.80).

A ironia seria a produção que se estabelece no jogo entre o estado de mundo cristalizado (com seus sentidos estabilizados) e outros possíveis estados de mundo, o que lhe confere o status de um tipo de discurso também. Nessa acepção, afasta-se por completo a idéia de ironia como desvio - tão propalada por autores vinculados a outras abordagens teóricas -, atribuindo-lhe o papel de elemento constitutivo no processo de significação. O estatuto de arbitrariedade e pessoalidade do locutor é enfraquecido por esse viés teórico, já que, como afirma Orlandi, é possível que, no uso, um enunciado que não é propositadamente irônico pode vir a sê-lo (ibid., p. 80). Tratar-se-ia, pois, de um procedimento discursivo em que outros estados de mundo seriam engendrados independentemente do enunciador -, rompendo-se com o discurso do senso comum e deslocando sentidos.

Nessa parte do estudo, gostaríamos de trazer algumas considerações teóricas relevantes de Ferreira (2000), as quais envolvem a distinção entre os conceitos de ambigüidade e equívoco, de um ponto de vista epistemológico, e que nos interessam nessa discussão. A autora comenta que a ambigüidade, ao longo dos estudos lingüísticos, sempre teve uma conotação negativa, ou seja, sempre foi vista como um elemento a ser evitado e descartado, já que estaria ligado à idéia de excesso no texto, que tanto poderia agregar-lhe humor ou poesia (algo, de qualquer forma, condenável a um bom texto).

\footnotetext{
1 Nesse caso, poderíamos fazer uma aproximação com os estudos de Authier-Revuz (1998), particularmente, sobre a heterogeneidade constitutiva dos discursos, em oposição à heterogeneidade mostrada, em que o sujeito tenta demarcar, na enunciação, uma autoria diferente, como se todo o resto pertencesse a ele.
} 
Isso nos dá uma pista de que a ambigüidade está em estrita associação com o lugar da irrupção do equívoco da língua. Se a língua, do ponto de vista de certos estudos lingüísticos, é vista como transparente e lógica, exclui-se dela toda a possibilidade do equívoco constitutivo, ou seja, quando há ambigüidade, há erro (seja do ponto de vista gramatical, lexical ou sintático, por exemplo), há desvio da norma.

Assim, segundo Ferreira (2000, p. 51), prevalece a lógica do ou, ou seja, da disjunção, que caracteriza a chamada "língua de madeira" pecheutiana (PÊCHEUX e GADET, 2004). Do ponto de vista discursivo, porém, a ambigüidade é constitutiva da língua, inerente a todo discurso, pois a "língua, ao se mostrar, esconde" (FERREIRA, 2000, p. 65). Embora haja uma regularidade na língua determinada por sua estrutura, há o histórico imbricado a ela, responsável pelos sistemas de dispersão (FOUCAULT, 2004, p. 43) de sentidos. Assim, apesar de se buscar um fechamento, a língua escapa. Ferreira (2000, p. 66) comenta, como exemplo desse funcionamento na língua, o uso das incisas ${ }^{2}$ (o qual foi também bastante discutido por Haroche, 1992), já que "os elementos determinativos que são tidos como especificadores no domínio das marcas formais da língua, servem à indeterminação no domínio do discurso".

Portanto, a língua numa perspectiva discursiva não segue a lógica do ou. Se fosse possível fazer uma analogia em relação a algum tipo provável de lógica, teríamos a da inclusão, a do $e$, pois o sentido se constrói segundo a idéia do duplo (FERREIRA, 2000, p. 70). A autora também inclui na discussão a questão da presença do humor como o momento em que se produz certo estranhamento, o qual se estabelece entre a zona do sentido e não-sentido, podendo ou não provocar o riso (nem sempre a ironia causa graça, mas, sempre, um estranhamento). No entanto, essa forma de se manifestar na língua que nomeamos, discursivamente, como equívoco constitutivo pode aparecer como falta (elipse), excesso (incisa), repetição, absurdo, etc., ou seja, como lugares em que se joga com a língua. Em todos os casos, porém, identifica-se "a ruptura do fio discursivo e o impacto efetivo na condição de fazer e desfazer sentidos" (ibid., p. 108).

Assim, nossa proposta de estudo é trabalhar com a ironia, nos recortes discursivos de textos jornalísticos, como uma construção da linguagem que participa do discurso, pois provoca efeitos de sentido não esperados ou previstos na língua de madeira, tão buscada pelo discurso jornalístico. Há, no discurso que chamaremos de irônico, diferentes maneiras de se recuperar o já-dito (pertencente à esfera da interdiscursividade e da intertextualidade). No entanto, o que se sugere é que não há uma coincidência entre o dizer e o querer dizer, pois há uma mera ilusão de controle da posição sujeito-enunciador sobre o que diz, já que, na construção irônica, funciona uma dupla enunciação. A posição sujeito-enunciatário como receptor também é invocada para que a ironia se concretize como espaço, mais do que de ambigüidade, de equívoco.

\footnotetext{
${ }^{2}$ Segundo Haroche (1992, p.128-129), a incisa é uma "expressão que rompe a completude do discurso pelo acréscimo supérfluo", acréscimo que se relacionaria não precisamente ao conteúdo da proposição, mas às idéias e opiniões do sujeito que enuncia.
} 


\section{ANÁlise dAS CHARGES ${ }^{3}$ HUMORÍSTICAS E DOS RECORTES DE REPORTAGENS}

De uma seleção de 11 quadrinhos humorísticos impressos na seção Opinião do jornal Folha de S. Paulo, de 16 a 26 de maio, que se referem, de alguma forma, aos discursos sobre os atentados do PCC, traremos para a discussão cinco deles, que comporão, juntamente com alguns outros recortes discursivos de reportagens, o nosso corpus de análise.

O primeiro (figura 1) que data do dia 16 de maio, é de autoria de Angeli, cartunista que colabora regularmente com o jornal:

(Fonte: ANGELI, 16/5/2006, p.2)

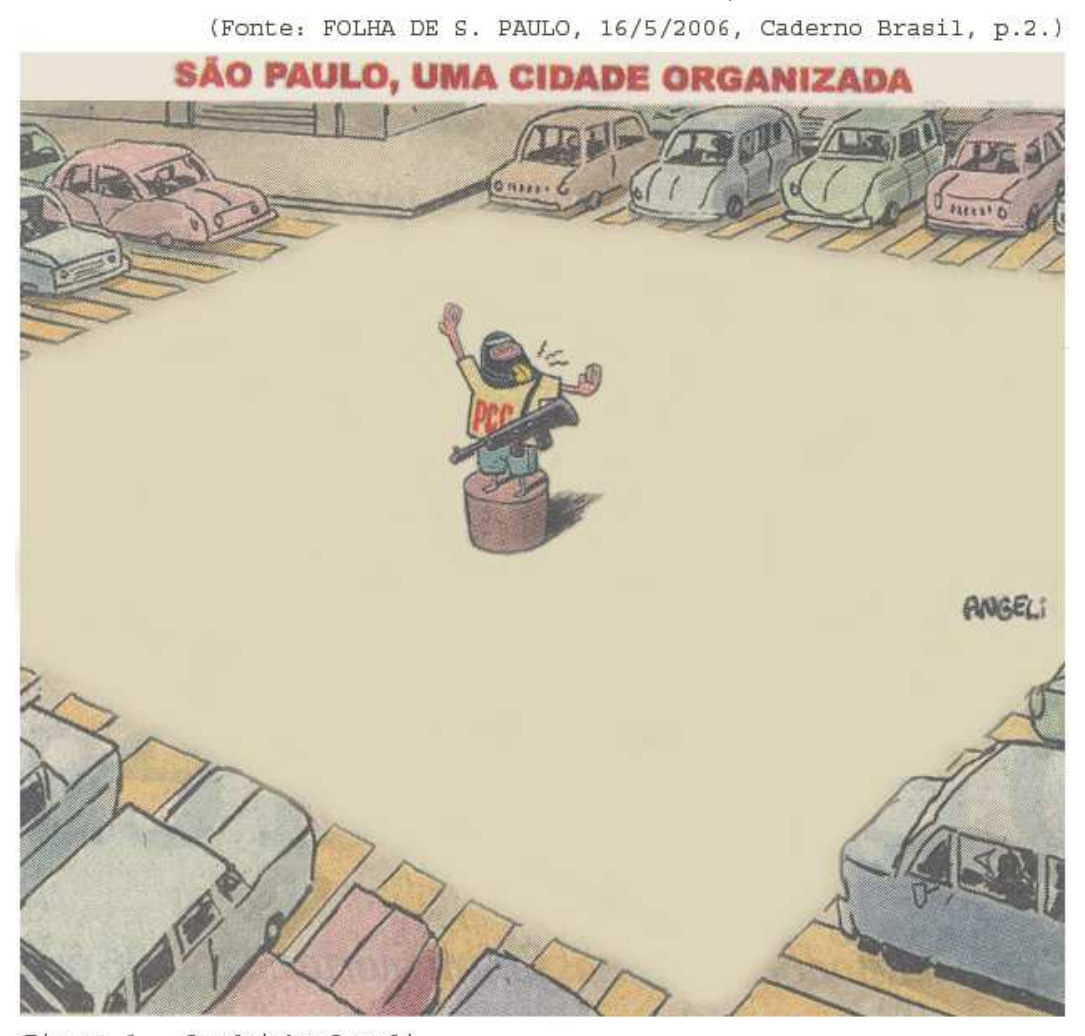

Figura 1 - Quadrinho Angeli

Figura 1 - Quadrinho de Angeli.

Fica impossível não remeter o quadrinho a outros textos do jornal (intertextualidade) e a outros discursos que constituem a memória discursiva, considerando principalmente as formações discursivas dos leitores do jornal. Como exemplo, temos o pronunciamento realizado anteriormente pelo secretário de segurança pública paulista, Saulo de Castro Abreu, no mesmo jornal, o qual afirmara que o PCC, como um movimento de organização criminosa, havia sido desarticulado pela polícia paulista.

Partindo para a análise da materialidade lingüística do quadrinho, ao substantivo próprio São Paulo é acrescentado um aposto: uma cidade organizada, que funciona

\footnotetext{
${ }^{3}$ Segundo o dicionário Aurélio (Ferreira, 1975, p. 314), o termo de origem francesa refere-se a uma representação pictórica, de caráter burlesco e caricatural, em que se satiriza uma idéia, situação ou pessoa. Utilizaremos aqui também o termo quadrinho (humorístico) como sinônimo.
} 
como uma incisa que lhe atribui tal característica. No entanto, essa incisa, cujo propósito poderia ser o de um fechamento de sentido na atribuição de uma qualificação, ao nos referirmos à ilustração, produz um outro efeito de sentido: se a cidade está organizada, ela o está, estranhamente, pelas mãos de uma organização criminosa. Lingüisticamente, o sintagma cidade organizada remete, também, a essa incompletude de sentido, pois, ao sugerir a organização da cidade, abre-se espaço para a pergunta: quem a teria organizado? A informação, que não aparece explicitamente no enunciado lingüístico e que caracterizaria uma construção elíptica, pode então ser sugerida a partir da ilustração, que indica quem estaria executando tal tarefa: os membros do PCC.

Temos, portanto, pelas duas vias de análise lingüística (incisa e elipse), um duplo sentido instaurado, que remete à estruturação da ironia, a qual se caracteriza pela interferência de séries: aqui, no caso, a ambigüidade se estabelece entre o dizer e a imagem, sendo que a última luta com o sentido pretensamente estabilizado do enunciado, particularmente do adjetivo organizada, instaurando, primeiramente, um estranhamento e, depois, o efeito de humor naqueles que ocupam a posição de leitores. Esse estranhamento vem a acontecer pela (con)ocorrência de elementos que não eram esperados. No entanto, isso só produzirá um efeito de ironia se os leitores, ainda que assujeitados às suas formações discursivas, perceberem o deslocamento possível de sentidos do texto, aqui considerado em sua dimensão imagem-texto.

Há certos indícios que levam à produção do efeito de ironia no quadrinho: Angeli é um cartunista e humorista que escreve regularmente na Folha, portanto, sua função é bastante conhecida dentro do jornal (criticar a partir do humor). Outro fator é que os leitores do jornal teriam acompanhado também pelo noticiário (divulgado pelo jornal citado e por outros veículos informativos) os comentários anteriores das autoridades, que teriam dito ter aniquilado a organização criminosa, a qual aparece, agora, em evidência nesses acontecimentos. O próprio fato de chamar o PCC de organização criminosa é significativo e causa um certo estranhamento, que também é evocado para a realização do efeito da ironia: como poderia um grupo de presos, a grande maioria confinada a presídios de segurança máxima, ser responsável pela organização de uma facção criminosa cuja ação dar-se-ia fora dos presídios e que causaria tantos efeitos em diferentes segmentos da sociedade?

Outro aspecto que nos causa interesse é o que diz respeito à pretensa tentativa de imparcialidade do discurso jornalístico. O quadrinho de Angeli aparece na seção Opinião do jornal, o que, de alguma forma, procuraria isentar esse veículo da responsabilidade pela posição do humorista, já que o jornal privilegiaria sua dimensão informativa e objetiva, o que nos parece condizer mais com um efeito do imaginário construído do que com a própria realidade, já que o jornal sempre representará uma ideologia através das formações discursivas que constituem suas vozes (MARIANI, 2003, p. 35) e, uma vez que é uma concessão pública, não deixa de sofrer processos de autocensura para a manutenção do direito que lhe foi concedido.

Remetemo-nos, agora, a outro quadrinho (figura 2) de Angeli também, que foi impresso no mesmo jornal, no dia 18 de maio, na mesma coluna, Opinião: 
(Fonte: ANGELI, 18/5/2006, p. 2)

(Fonte: FOLHA DE S. PAULO, 18/5/2006, Caderno Brasil, p.2.) ACORDO COM BANDIDO

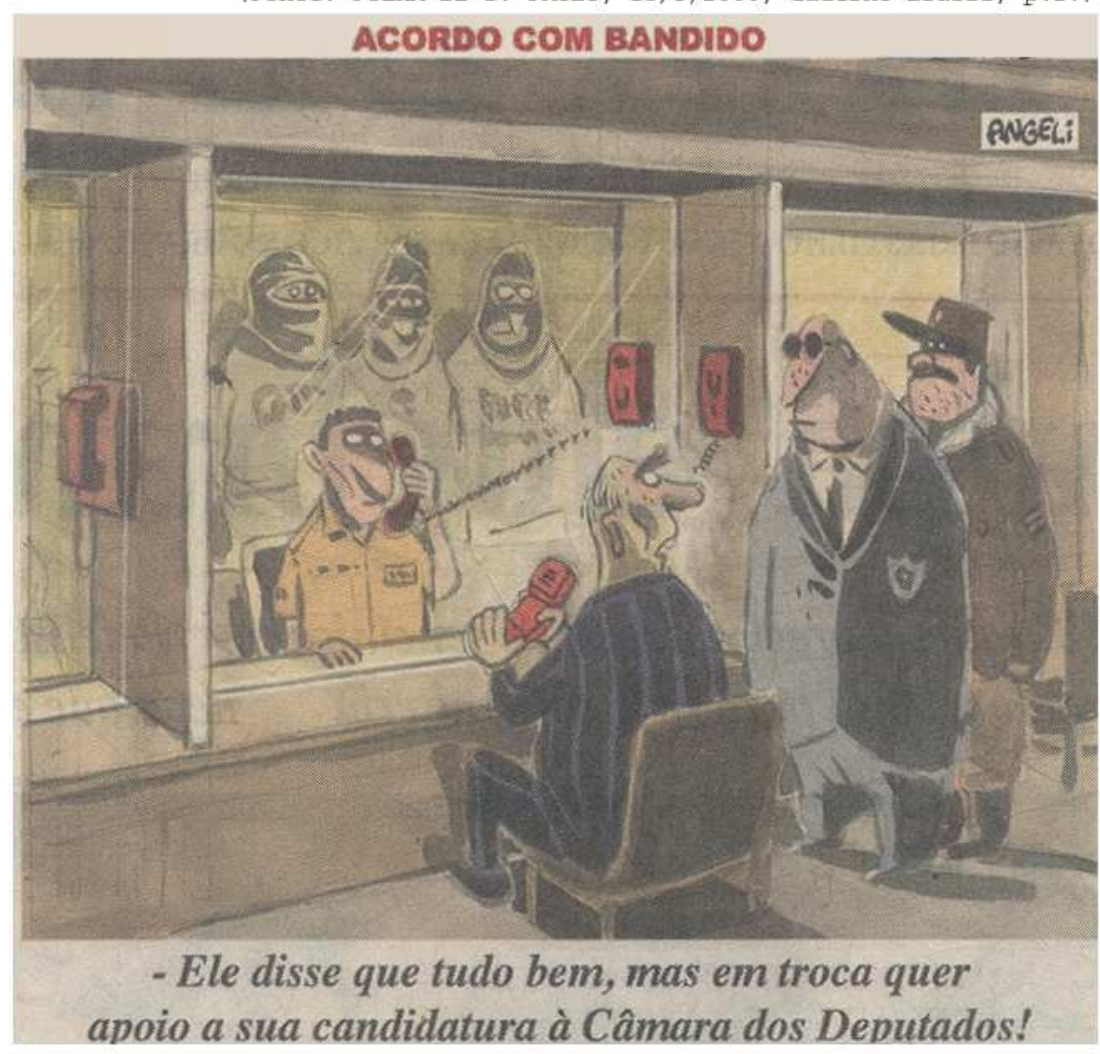

Figura 2 - Quadrinho Angeli

Figura 2 - Quadrinho de Angeli.

O efeito irônico estabelece-se a partir da inter-relação do quadrinho com outros textos do jornal, já publicados na semana, e de outros discursos que circularam a respeito da negociação entre autoridades políticas e policiais com os presos mandantes dos atentados da chamada Guerra Urbana. Como exemplo, trazemos aqui um recorte da notícia publicada no dia 16 de maio, do mesmo jornal, cujo título era Cúpula do PCC ordena fim de ataques, a qual era acompanhada pelo seguinte olho: "Ordem foi dada a membros da facção após dois dias de conversas com representantes do governo estadual, que nega negociação". Extraímos abaixo apenas o primeiro parágrafo da notícia no qual se tem um resumo do acontecimento descrito na reportagem:

A cúpula do PCC (Primeiro Comando da Capital) deu ordem ontem para cessar os atentados e rebeliões em São Paulo, após dois dias de conversas com representantes do Estado. (CÚPULA..., 16/5/2006, p.2.)

Embora o jornal exponha aquilo que acredita ser o fato, dá espaço para o outro lado, nesse caso, dá a voz aos políticos, para darem a sua versão dos acontecimentos, concluindo, ao final da reportagem, que "o governo nega negociação com a facção", o que reafirmaria a imparcialidade do veículo diante das diferentes versões. Em reportagem do dia 17 de maio, do mesmo jornal, confirma-se a negociação entre autoridades e membros do PCC em Presidente Bernardes, presídio de segurança máxima que abrigaria os chefes da facção. A manchete diz: Comitiva foi de avião negociar com o PCC e o olho da reportagem complementa: "Governo nega acordo, mas 
confirma que advogada teve acesso à cúpula da facção, que está em isolamento em presídio do interior" (COMITIVA..., 17/5/2006, p. 2).

Percebe-se, aqui, que o fato narrado pelo jornal, ao qual este veículo parece creditar a verdade por suas apurações através de jornalistas diversos (três diferentes jornalistas assinam a matéria), é de que houve negociação entre os políticos e autoridades com os chefes da organização criminosa (tanto é que a notícia ocupa dois terços da página, enquanto a negativa do governo se dá em dois parágrafos). É exatamente essa verdade que o humorista vai explorar ambigüamente, no quadrinho (figura 2), cujo título é Acordo com bandido.

O acordo, em questão no quadrinho, é dúbio. Primeiro há uma elipse na construção lingüística que não aborda, explicitamente, a qual acordo se refere o título (embora os leitores saibam discursivamente ao que ele se remete). Outro ponto que pode ser explorado na análise, é que, embora acordo refira-se, lingüisticamente, ao sintagma com bandido, discursivamente, pode-se fazer outros gestos de interpretação, que resgatam outros sentidos de bandido, relacionados ao contexto sócio-histórico atual: quem seriam os bandidos, no caso, uma vez que o prisioneiro aceita um trato (disse que tudo bem) condicionado à sua candidatura, nada mais nada menos, que "à Câmara dos Deputados", casa do poder legislativo, formada por muitos membros que estavam envolvidos, naquele mesmo momento histórico, em diversos escândalos de desvio de dinheiro, que estavam bastante vivos na memória dos brasileiros, como o caso das sanguessugas?

Sendo assim, o duplo sentido recai sobre o que o leitor do jornal interpreta como o imaginário de bandido e, igualmente, de deputados, nesse quadro político-social. Nessa cumplicidade com a posição discursiva dúbia do humorista, a ironia se estabelece. O efeito irônico, aqui, mais do que produzir graça, cria um espaço de crítica. No entanto, é importante ressaltar que, dependendo da formação discursiva do sujeito, os efeitos de sentido serão diferentes. Imagine-se, por exemplo, um sujeito cujas formações discursivas remetam a uma atividade política: é provável que a ironia fosse tomada como uma situação de confronto. Isso coloca em xeque a transparência da língua: não existem sentidos fechados; eles são trabalhados, discursivamente, através das formações discursivas que remetem, por sua vez, a formações sócio-ideológicas. Daí o jornal esquivar-se do comprometimento com a verdade sugerida pelo humorista (o jornal compromete-se com a sua verdade única), atribuindo-lhe um lugar marginal no jornal, na coluna Opinião.

Um terceiro quadrinho (figura 3) que selecionamos para essa análise é o do dia 19 de maio, do mesmo jornal, de autoria do chargista Jean. Composto por uma seqüência de duas ilustrações, registra duas falas de uma mesma personagem, em dois momentos diferentes: 
(Fonte: JEAN, 19/5/2006, p. 2)

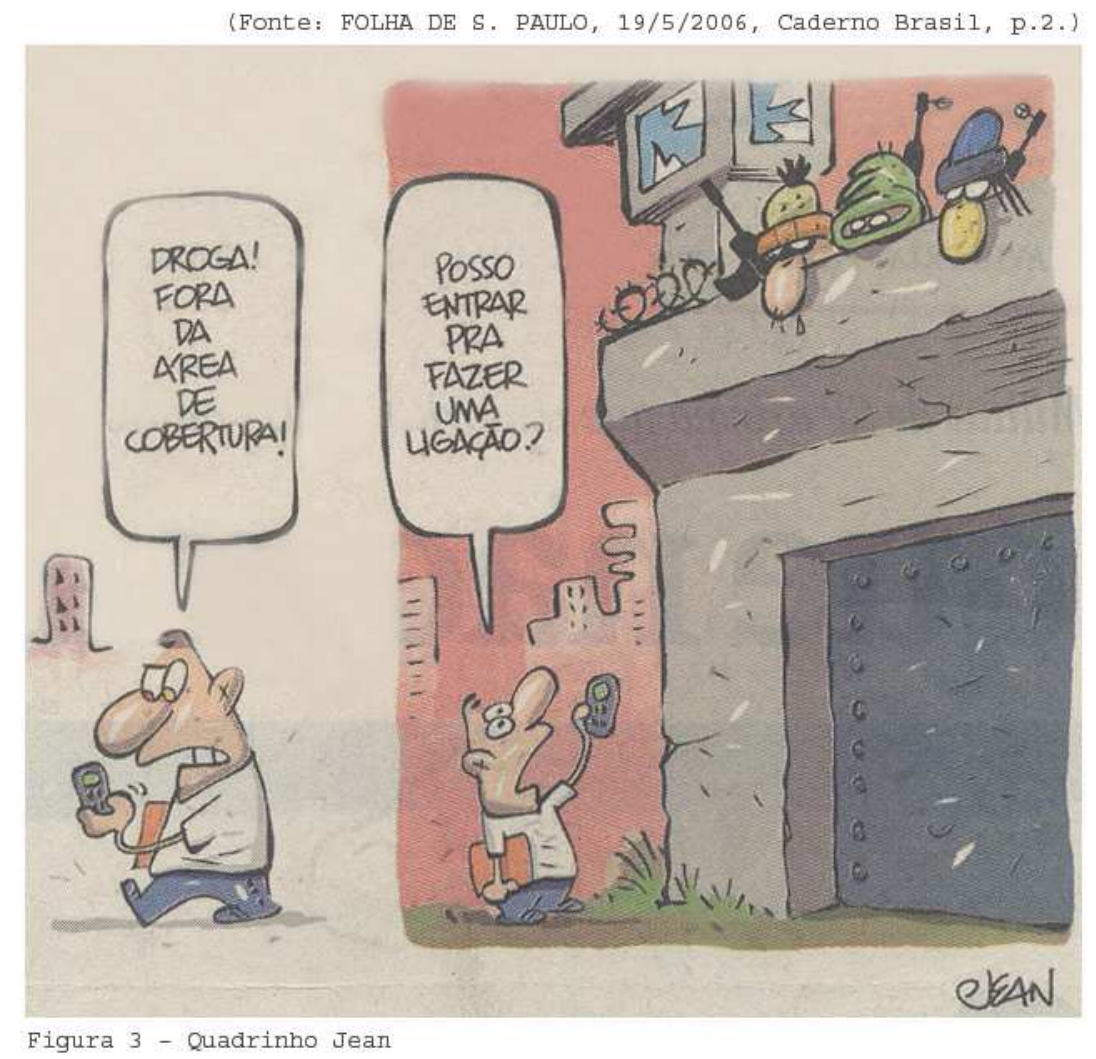

Figura 3 - Quadrinho de Jean.

Num primeiro gesto de leitura superficial, parece instaurar-se a idéia de um absurdo: quem entraria num presídio em rebelião para fazer uma ligação de celular? A ironia, muitas vezes, não tem comprometimento com uma verdade factual, pois se constrói no absurdo, no nonsense, com o intuito de, deliberadamente, desmascarar aquela verdade que se constrói e mantém pela suposta transparência da língua. Nesse caso, por exemplo, o leitor não compactua da realidade absurda criada pelo quadrinho: sabe que a personagem não deseja entrar no presídio para fazer uma ligação, mas compreende a que esses dizeres se referem. Essa questão remete à não-coincidência do discurso consigo mesmo (BRAIT, 1996, p. 110), característica que o discurso irônico sugere ao recuperar um já-dito ${ }^{4}$, que se constrói a partir do vínculo com outros textos (aqui, inclusive, com textos do próprio jornal) e outros discursos, através do compartilhamento do sistema de referências com o receptor. É o receptor que interpretará a presença de um discurso já-dito em outro contexto, o que remete ao caráter de simulação proposto pelo recurso da ironia.

A propósito desse quadrinho, citamos como exemplo da intervenção de séries que tem como objetivo produzir o efeito irônico - caracterizada aqui como um diálogo entre textos - as reportagens que saíram na Folha a respeito da decisão judicial de se interromper os sinais de celular recebidos e advindos nas prisões. Primeiramente, a notícia do dia 18 de maio, impressa no caderno Cotidiano, cuja manchete é: Juiz manda bloquear celular em prisões, que é seguida pelo olho de reportagem em que aparecem

\footnotetext{
${ }^{4}$ A idéia do já-dito de Brait está associada, na discussão orlandiana sobre a ironia, à concepção do mesmo, que, por esse funcionamento, passa a existir na diferença.
} 
os dizeres: "Medida, que pode ser ampliada, será adotada dentro de unidades prisionais de seis cidades do Estado por pelo menos 20 dias" (JUIZ..., 18/5/2006, p. 5). Segue, então, a reportagem principal, explicando como se dará o bloqueio do funcionamento do serviço, e mais duas complementares: uma sobre como o governo iria compensar as operadoras pelo serviço e outra sobre os custos desse trabalho. Outra notícia, ainda, que estaria relacionada ao quadrinho saiu no mesmo dia de sua impressão, na página 7 , com o título: Suspender sinal pode não ser $100 \%$ eficaz. Havia, ainda, um comunicado oficial da Anatel, agência que controla o serviço de telefonia, que foi impresso como informe publicitário (portanto, pago pela própria agência) na mesma página, dizendo que a agência estaria implementando imediatamente um plano técnico para cumprir as exigências do poder judiciário.

Não nos interessa aqui analisar tais reportagens, mas estabelecer a relação delas com o quadrinho humorístico, uma vez que, sua interpretação irônica depende da correlação que se estabelece com esses outros textos, produzidos no mesmo contexto histórico. No entanto, a ironia não se estabelece somente na intersecção de textos, mas também com a memória discursiva e os diferentes discursos produzidos (interdiscurso). Nesse caso, temos a inter-relação dos discursos publicitário (o comunicado da Anatel), jurídico (determinação judicial) e jornalístico (vários que aparecem nesse veículo e em outros) com o discurso do quadrinho, produzindo o efeito humorístico.

É interessante mencionar também que, para aqueles sujeitos-leitores do jornal que compartilham os problemas da personagem do quadrinho em relação à telefonia celular, isso pode, também, constituir-se como um elemento de identificação com o quadrinho, o que contribui para a construção da intervenção de séries e para o efeito da ironia.

Tomemos, agora, para a análise, dois últimos quadrinhos. Um deles é de Glauco e foi publicado na Folha, no dia 20/05 (figura 4). O outro, de autoria de Angeli, é do dia 21/05 (figura 5), ambos aparecem na coluna Opinião: 
(Fonte: GLAUCO, 20/5/2006, p. 2)

(Fonte: FOLHA DE S. PAULO, 20/5/2006, Caderno Brasil, p.2.)

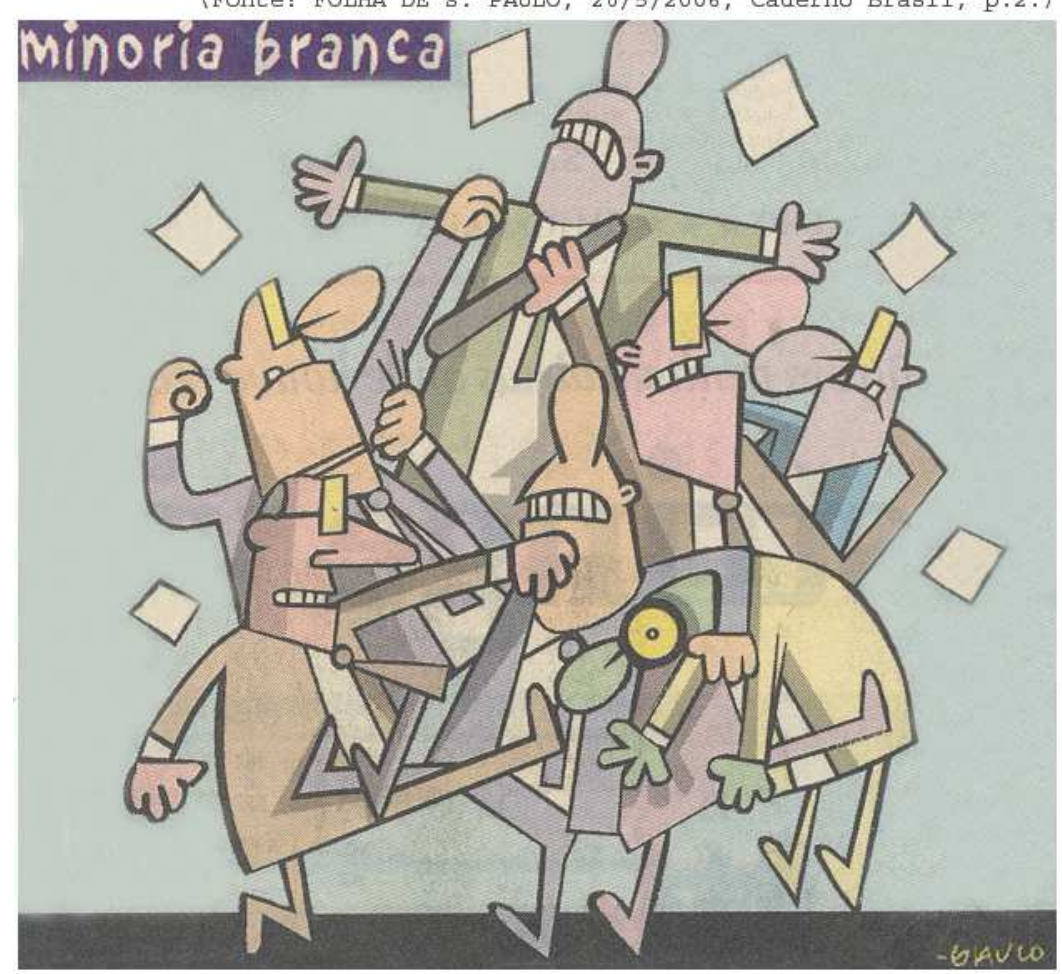

Figura 4 - Quadrinho Glauco

Figura 4 - Quadrinho de Glauco. 
(Fonte: ANGELI, 21/5/2006, p. 2)

(Fonte: FOLHA DE S. PAULO, 21/5/2006, Caderno Brasil, p.2.)

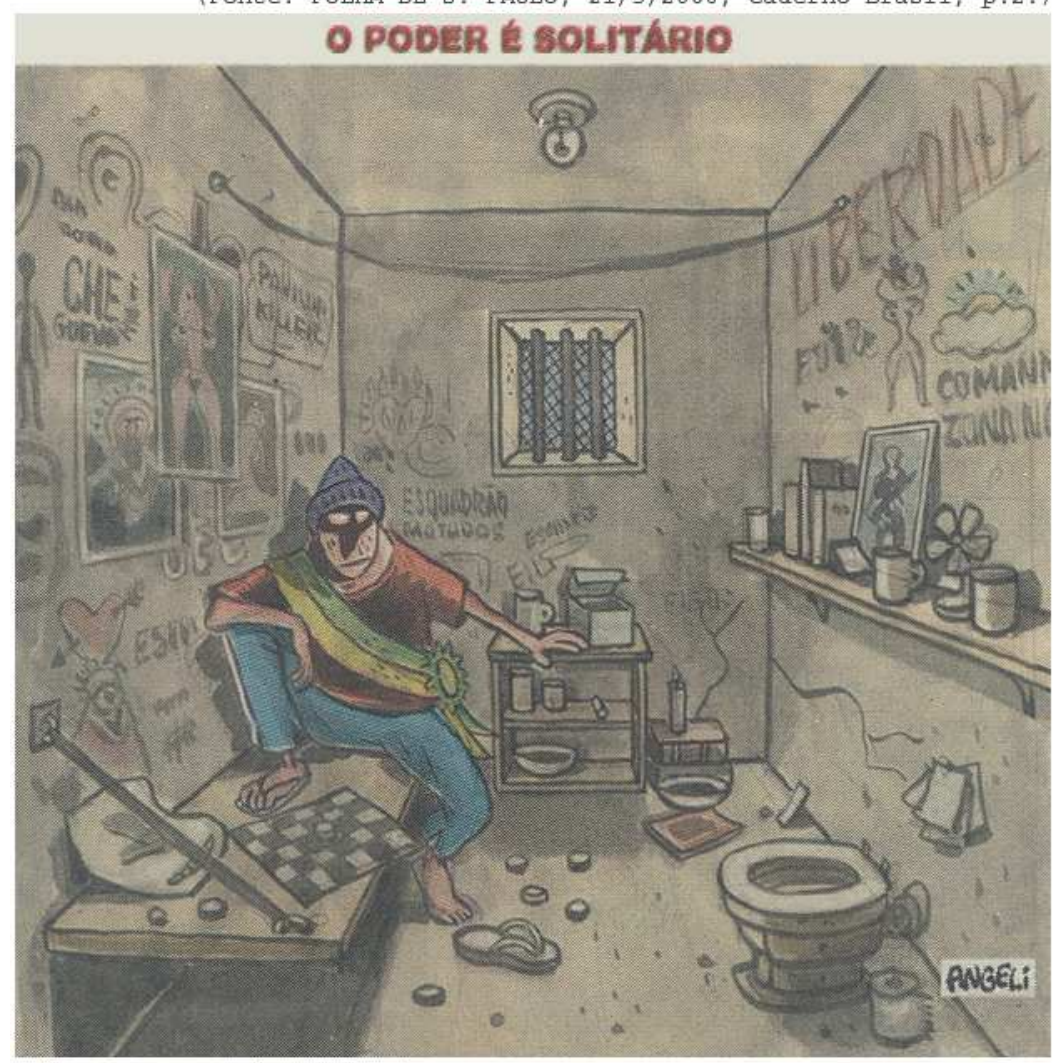

Figura 5 - Quadrinho Angeli

Figura 5 - Quadrinho de Angeli.

Trazemos os dois quadrinhos em sincronia, pois ambos parecem remeter-se a uma entrevista dada pelo governador de São Paulo, Cláudio Lembo, ao mesmo jornal. Nela o governador tece suas considerações sobre os eventos do PCC, as ações da polícia e, principalmente, sobre as possíveis causas do problema. Levantamos aqui dois recortes da entrevista que parecem ser os privilegiados pelos chargistas na construção dos quadrinhos aos quais nos referimos anteriormente e que foram tomados como base para a composição das seqüências cômicas, através da interferência de séries dos textos. sublinhado:

Observemos, então, o primeiro recorte da entrevista, com destaque ao trecho

O Brasil está desintegrado e perdeu seus valores cívicos. É ridículo falar isso mas o Brasil só acredita na camisa da seleção, que é símbolo de vitória. É um país que só conheceu derrotas. Derrotas sociais... Nós temos uma burguesia muito má, uma minoria branca muito perversa (...) Se nós não mudarmos a mentalidade brasileira, o cerne da minoria branca brasileira, não vamos a lugar nenhum. (...) A bolsa da burguesia vai ter que ser aberta para poder sustentar a miséria social brasileira (LEMBO, 18/5/2006, p. 7, grifos nossos).

Em relação ao quadrinho de Glauco (figura 4), cujo título é Minoria branca, o mesmo sugere, na articulação da linguagem verbal com a linguagem visual, que aqueles homens que representam o poder (engravatados) formam a chamada minoria branca, à qual o governador reportou-se em sua entrevista. Há aqui a intervenção, a imbricação de 
séries constitutivas dos dois textos, que leva o leitor do quadrinho a compartilhar a ambigüidade de sentidos, ao estabelecer a relação entre ambos. A seriedade do discurso político representado pela fala do governador (que representa também um lugar de poder) é então colocada em jogo na charge de Glauco, levando ao humor.

Segundo Žižek (1992, p. 60), o discurso irônico confronta “as frases patéticas da ideologia vigente com a banalidade, as ridiculariza, mostrando o interesse (...) a sede ilimitada do poder por trás da sublime nobreza das frases ideológicas". Tal discurso funcionaria, ainda, pela redução de um enunciado ideológico à sua situação de enunciação (como já levantara Brait em seu estudo). Assim, a frase de efeito do governador (algo como "nós temos uma burguesia muito má, uma minoria branca muito perversa") passa pelo quadrinho reduzida à sua condição de enunciação, que, na combinação com a ilustração, perde todo o efeito de uma suposta seriedade. É na ruptura com esse discurso que se pretende lógico e sem espaço para a equivocidade (o qual remete ao senso comum ${ }^{5}$ ) que a ironia se instaura, confrontando o regime de verdades que atravessa os dois textos. Voltaremos, ainda, a esse excerto da entrevista para algumas outras considerações analíticas considerando mais amplamente o discurso irônico dentro do discurso jornalístico.

Voltemo-nos, agora, para o segundo recorte da mesma entrevista, atentando-nos para o destaque sublinhado, o qual trabalharemos em associação com o quadrinho de Angeli (figura 5):

\begin{abstract}
No poder, um homem é absolutamente solitário. Houve momentos em que praticamente fiquei sozinho. Mas devo agradecer a polícia Militar e a Polícia Civil também, que estiveram firmes ao meu lado (LEMBO, 18/5/2006, p. 7, grifos nossos).
\end{abstract}

Se as palavras do governador procuram remeter a um sentido fechado, da solidão em que se encontrou no momento da crise causada pelos atentados do PCC, o quadrinho de Angeli aborda uma relação diferente de sentido, que causa o efeito de humor no discurso. O quadrinho é introduzido pelo dizer "O poder é solitário". Até aí poderia reforçar o discurso do governador ("no poder, um homem é absolutamente solitário"). No entanto, a ilustração abre para um outro efeito de sentido que, embora ainda esteja atrelado ao texto da entrevista, produz uma interpretação diferente. No quadrinho vê-se um prisioneiro sozinho numa cela solitária, com uma faixa verde e amarela atravessada em seu corpo, que parece remeter-se a uma representação imaginária de alguém no exercício do poder público.

É possível estabelecer a relação entre os dizeres do governador na entrevista da Folha "no poder, um homem é absolutamente solitário" com o dizer "o poder é solitário". No entanto, o que causa humor, através do efeito da intervenção de textos e discursos (recurso de linguagem da ironia), é que o dizer aqui produzido o poder é solitário refere-se não (só) ao governador, mas ao poder dos presos, no caso, daqueles que exercem também o poder de dentro de suas celas, ainda que em isolamento. Há o diálogo entre os dois textos, mas também com outros discursos que podem não aparecer no nível intradiscursivo, mas que fazem igualmente parte da memória discursiva

\footnotetext{
${ }^{5}$ Seguindo as reflexões de Lagazzi (1988) sobre o senso comum, referimo-nos aqui ao discurso que visa à normatização (à norma que endireita, que iguala tudo e todos) e a literalidade (a busca pelo sentido único e transparente), ou seja, a "vontade de verdade" que tenta anular o conflito, simplificando e homogeneizando as idéias de tal forma que elas pareçam naturalizadas e que se imponham como verdade única.
} 
(interdiscurso). Como exemplo, há o nome Che Guevara inscrito na parede, que já remete a uma infinidade de outros discursos (e textos, naturalmente) revolucionários, pertencentes a formações discursivas completamente diversas da posição que o governador encontra-se (como veremos, logo abaixo, outro jornalista da Folha abordará a comparação entre Che e Lembo). O que causa estranhamento é a mudança radical na construção de sentido proposta pelo quadrinho, quando desvia a questão do poder do Estado (representado pelo governador) para o poder da organização criminosa, representada pelo preso solitário na cela.

No que diz respeito à linguagem, a construção estabilizada semanticamente $o$ poder é solitário passa a suscitar diferentes leituras, as quais estão imersas na historicidade do momento. A ambigüidade na língua produz o efeito do humor, mas também remete à crítica da situação social atual. Portanto, a ironia passa a ser uma estratégia de linguagem para burlar o efeito de evidência dos sentidos das palavras.

Retomando o primeiro excerto sobre a entrevista com o governador, ampliaremos, neste momento, nossa análise da construção irônica para outros espaços do jornal. $\mathrm{Na}$ análise lingüística do trecho "Nós temos uma burguesia muito má, uma minoria branca muito perversa", podemos, primeiramente, destacar que o governador fala da "burguesia muito má", da "minoria branca muito perversa", mas parece excluirse do grupo (pelo menos daquela parte restrita que considera "muito má" e "muito perversa"). A incisa "uma minoria branca muito perversa" vem especificar e também delimitar o grupo social ao qual o governador primeiro se refere (burguesia), talvez na tentativa de excluir-se dele, já que não deixa de pertencer economicamente à chamada "burguesia". No entanto, ao especificar o grupo como "minoria branca muito perversa" não há como não aludirmos também ao conflito de raças (também presente na memória discursiva), já que também é branco. Portanto, isso escapa da possibilidade da língua de conter o sentido. $\mathrm{O}$ enunciador (governador) tenta, no entanto, delimitar ainda mais esse grupo com as expressões minoria e muito perversa a fim de evitar a possibilidade de abrirmos o leque de sentidos até chegarmos à sua formação social especificamente. Entretanto, como a língua não é transparente e está inserida num jogo de interpretações vinculado à história, os sujeitos assumem diferentes posições no discurso, ao mesmo tempo que diferentes gestos de sentido são realizados por eles.

Assim, embora o enunciador (governador) tenha a ilusão de que controla o sentido do que diz e de que é a origem desse dizer, a língua demanda sempre por novos sentidos. Isso ficaria mais claro se expuséssemos as diferentes leituras realizadas por vários leitores da entrevista do governador, as quais apareceram destacadas na seção Painel do Leitor do mesmo jornal, nos dias subseqüentes. No entanto, pela brevidade deste trabalho e pelo foco na produção do efeito irônico no discurso jornalístico, destacamos, aqui, somente um recorte da coluna assinada pelo jornalista Clóvis Rossi (ROSSI, 24/5/2006, p. 2), em que este comenta a entrevista do governador ao jornal.

A começar pelo título, o jornalista é bastante irônico: Che Lembo, a piada, pois associa a figura do governador (especificamente seu discurso em oposição à elite branca) com o discurso revolucionário de esquerda de Che Guevara (que é tomado como parte da memória discursiva), cujo nome já aparecera destacado no desenho de Angeli (figura 5). Aí já temos o elemento da ironia instaurado: a intervenção de séries, de discursos, compondo um sentido inusitado.

$\mathrm{Na}$ posição de jornalista (portanto, que se deseja crítico e, ao mesmo tempo, objetivo), Rossi desenvolve, então, todo um raciocínio a fim de desconstruir o discurso do governador e, mais do que isso, a posição de submissão em que o governador se 
coloca na entrevista, justamente pelas formações sociais e ideológicas em que este se inscreve (ou se inscreveu) e que não poderiam ser negadas por ele. Daí o jornalista iniciar seu texto com as seguintes palavras: "Antes que a mídia e certos políticos transformem Cláudio Lembo no novo Che Guevara, uma breve ajuda-memória..." (ibid., p.2). Discorre, então, sobre as contradições do discurso do governador com suas posições políticas, sociais e econômicas, ao longo de sua vida política pública - como membro de partidos políticos conservadores: Arena, PDS e PFL (atualmente, Partido Democratas), os quais sempre defenderam os interesses da minoria branca - e vida privada (trabalhando ao lado do presidente do banco Itaú, uma das maiores instituições bancárias privadas do país, que também representa a dita burguesia).

O jornalista aborda, em seu texto, algo que, para nós, analistas do discurso, configurar-se-ia como as contradições constitutivas do discurso, o que nos permite relacioná-las às diferentes formações discursivas às quais o sujeito se inscreve - de modo inconsciente - e que são engendradas na história, revelando as relações de poder que se estabelecem entre os indivíduos, bem como os mecanismos sociais de controle vigentes. No entanto, o jornalista, tentando amarrar as contradições do discurso de Lembo, também cai na armadilha do controle sobre a língua (e do discurso), já que também não tem controle sobre o que diz. Falando de "dentro do jornal", coopta também uma posição de poder. Esse veículo de informação também faz parte da mídia, a qual critica no início do parágrafo. Não há, portanto, discurso jornalístico que não esteja impregnado dessas relações de poder e cuja busca pela objetividade seja apenas uma ilusão.

\section{CONCLUSÃO}

A partir da análise dos recortes discursivos que constituíram nosso corpus nesse estudo, pudemos discutir o papel da ironia como funcionamento discursivo de deslocamento no discurso jornalístico, o qual historicamente se projeta como imparcial, objetivo, transparente e que se pautaria no factual, uma vez que a verdade, assimilada aqui como uma vontade de verdade, é construída nas e pelas práticas discursivas. Daí o papel relevante que desempenha o discurso jornalístico como participante na construção da memória discursiva, selecionando aquilo que pode e deve ser lembrado em detrimento daquilo que se deseja silenciar, num determinado contexto histórico-social, determinado pelas formações discursivas.

No entanto, como a linguagem não é transparente, o equívoco da língua sempre emerge. Isso se dá, no discurso jornalístico, entre outros mecanismos de funcionamento da linguagem, principalmente, pela ironia. Por esse funcionamento, há a intervenção de discursos outros e de textos diversos, produzindo novos textos, e, em muitos casos, o efeito do humor, que ocasiona a ruptura do discurso ilusoriamente estabilizado do jornal.

Nos recortes discursivos aqui selecionados (quadrinhos e reportagens), percebemos, no uso da ironia, a abertura para outros gestos de interpretação no discurso jornalístico pretensamente sério e imparcial, produzidos a partir da inter-relação de outros discursos e textos que diziam respeito às ações do $\mathrm{PCC}$ e da polícia. $\mathrm{O}$ sujeitoleitor, compartilhando formações discursivas semelhantes, foi capaz de reconhecer tais gestos como ironia. Nos quadrinhos humorísticos, a linguagem verbal e a não-verbal atuam em conjunto na construção do efeito irônico, jogando com as possibilidades de 
subversão de sentidos pré-estabelecidos pelo discurso jornalístico. Essas rupturas se dão no interior do discurso, invocando o já-dito de maneira inusitada, e causam o estranhamento que, geralmente, leva ao humor. No entanto, não é somente nesses espaços do jornal que a ironia se faz presente. O discurso jornalístico é um espaço profícuo para as ambigüidades - e equívocos - que instauram a multiplicidade de sentidos, evidenciando a impossibilidade de uma língua transparente, de um discurso objetivo e de um texto estritamente informativo.

Portanto, o discurso jornalístico tende a priorizar o semanticamente normal, mas a língua como acontecimento escapa ao controle da razão e se mostra no equívoco, no estranho, no absurdo, no humor, na repetição, na ironia, quando, muitas vezes, temos o discurso do novo a partir do velho (como pudemos observar na repetição de enunciados que, quando aplicados a novos contextos, produzem novos discursos e configuram sentidos diversos). Assim, no entrecruzamento de discursos e textos, a ironia surge como uma possibilidade de ruptura com o mesmo, provando que não existe a univocidade entre palavras e coisas, entre frases e acontecimentos, entre significantes e significados, pois os sentidos se constroem em cadeia de associações que se configuram como possibilidades de interpretação na história que os engendra.

\section{REFERÊNCIAS}

ANGELI. Folha de S. Paulo, São Paulo, 16/5/2006. Caderno Brasil, seção Opinião, p. 2. . Folha de S. Paulo, São Paulo, 18/5/2006. Caderno Brasil, seção Opinião, p. 2. Folha de S. Paulo, São Paulo, 21/5/2006. Caderno Brasil, seção Opinião, p. 2. AUTHIER-REVUZ, J. Palavras incertas. Campinas: Editora da Unicamp, 1998. BERGSON, H. O riso. Rio de Janeiro: Zahar Editores, 1983.

BRAIT, B. Ironia em perspectiva polifônica. Campinas: Editora da Unicamp, 1996.

BRANDÃO, H. N. Introdução à análise do discurso. Campinas: Editora da Unicamp, 1995.

COMITIVA foi de avião negociar com o PCC. Folha de S. Paulo: São Paulo, 16/5/2006. Caderno Cotidiano, p. 2.

CÚPULA do PCC ordena fim de ataques. Folha de S. Paulo: São Paulo, 17/5/2006. Caderno Cotidiano, p. 2.

FERREIRA, C. L. Da ambigüidade ao equívoco. Porto Alegre: Editora da Universidade/UFRGS, 2000.

FERREIRA, A. B. de H. Novo dicionário Aurélio da língua portuguesa. Rio de Janeiro: Editora Nova Fronteira, 1975.

FOUCAULT, M. A arqueologia do saber. Rio de Janeiro: Editora Forense universitária. 2004.

A ordem do discurso. 8 $^{\text {a }}$. ed. São Paulo: Edições Loyola, 2002.

História da sexualidade I: A vontade de saber. Rio de Janeiro: Graal, 2001.

GLAUCO. Folha de S. Paulo, São Paulo, 20/5/2006. Caderno Brasil, seção Opinião, p.2.

HAROCHE, C. Fazer dizer, querer dizer. São Paulo: Hucitec, 1992.

JEAN. Folha de S. Paulo, São Paulo, 19/5/2006. Caderno Brasil, seção Opinião, p. 2.

JUIZ manda bloquear celular em prisões. Folha de S. Paulo: São Paulo, 18/5/2006.

Caderno Cotidiano, p.5. 
LAGAZZI, S. O desafio de dizer não. Campinas, Pontes, 1988.

LEMBO, C. Burguesia terá de abrir a bolsa. Folha de S. Paulo, São Paulo, 18/5/2006. Caderno Cotidiano, seção Entrevista, p. 7.

MARIANI, B. Os primórdios da imprensa no Brasil (ou: De como o discurso jornalístico constrói memória). In: Orlandi, Eni. Discurso fundador. Campinas: Pontes, 2003.

ORLANDI, E. Discurso fundador. Campinas: Pontes, 2003.

Destruição e Construção do sentido (um estudo da ironia). Série Estudos, v. 12.

Publicação do Curso de Letras do Centro de Ciências Humanas e Letras das Faculdades Integradas de Uberaba, 1986.

PÊCHEUX, M. O discurso: estrutura e acontecimento. Campinas: Pontes, 1997. Semântica e discurso. Campinas: Editora Unicamp, 1988. e GADET, F. A língua inatingível. Campinas: Pontes, 2004. et al. Papel da memória. Campinas: Pontes Editores, 1999.

e Fuchs, C. A propósito da análise automática do discurso: atualização e perspectivas. In Gadet, F. e Hak, T. (orgs.). Por uma análise automática do discurso: uma introdução à obra de Michel Pêcheux. Campinas: Editora da Unicamp, 1990.

ROSSI, C. Che Lembo, a piada. Folha de S. Paulo, São Paulo, 24/5/2006. Caderno Brasil, seção Opinião, p. 2.

SÁ, N. de. Sabe Deus. Folha de S. Paulo, São Paulo, 19/5/2006. Caderno Brasil, coluna Toda Mídia, p. 6.

SUSPENDER sinal pode não ser 100\% eficaz. Folha de S.Paulo: São Paulo, 19/5/2006. Caderno Cotidiano, p. 7.

ŽIŽEK, S. Eles não sabem o que fazem: o sublime objeto da ideologia. Rio de Janeiro: Jorge Zahar Editor, 1992. 